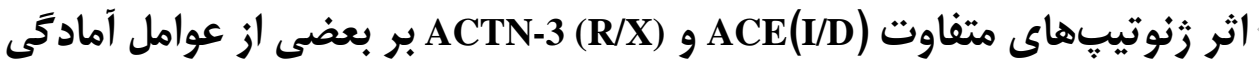

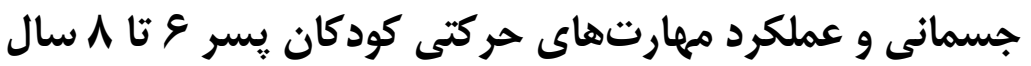

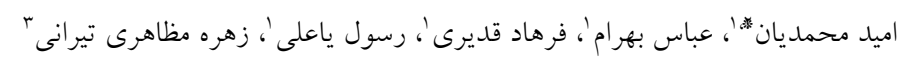

ا. كروه رقتار مركتى، دانشكدة تربيتبدنى 9 علوم ورزشى، دانشكاه خوارزمى، تهران، ايرلنغ

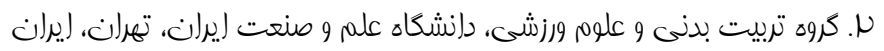

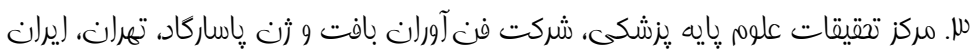

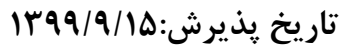

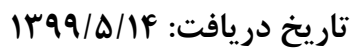

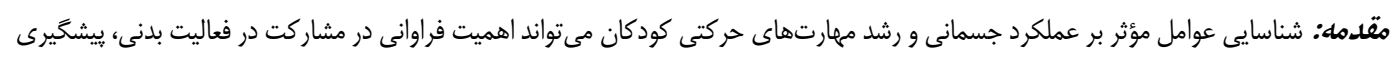

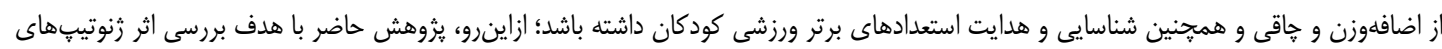

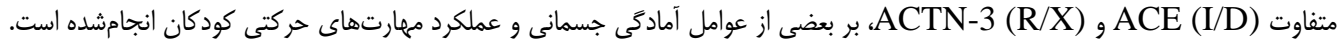

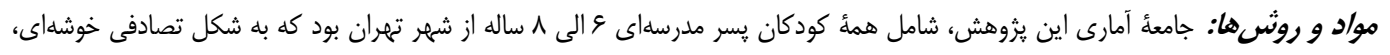

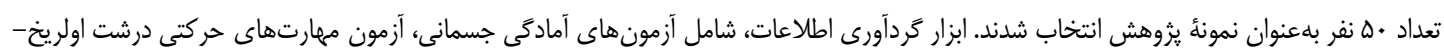

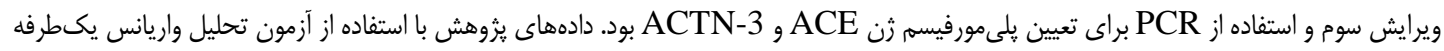

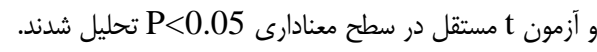

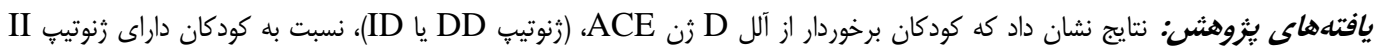

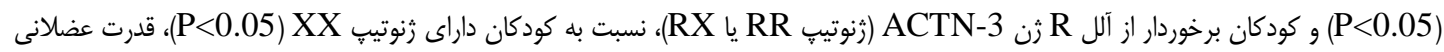

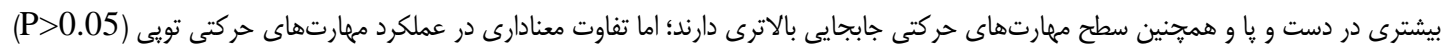
مشاهده نشد.

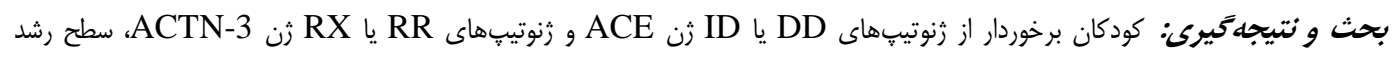

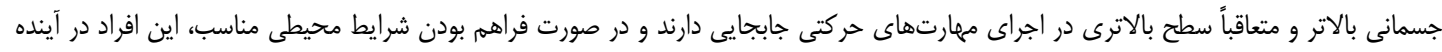

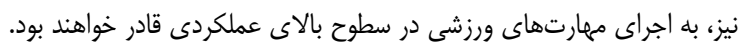

$$
\text { وازههاى كليدى: زنوتيی، فنوتيی، زن ورزشى، آمادگى جسمانى، رشد حركتى، كودكان }
$$

* نويسندة مسئول: تروه رفتار حركتى، دانشكدة تربيتبدنى و علوم ورزشى، دانشكاه خوارزمى، تهران، ايران Email: omohammadian10@gmail.com

Copyright () 2019 Journal of Ilam University of Medical Science. This is an open-access article distributed under the terms of the Creative Commons Attribution international 4.0 International License (https://creativecommons.org/licenses/by-nc/4.0/) which permits copy and redistribute the material, in any medium or format, provided the original work is properly cited. 
ACTN-3 جسمانى و عوامل نمو در كودكان را متأثر نمى كند أند

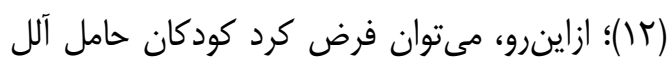

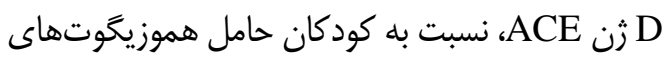

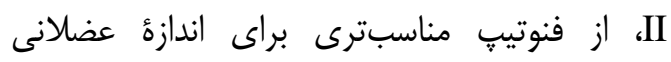
بزرگتر، قدرت و توان عضلانى بيشتر و متعاقباً از

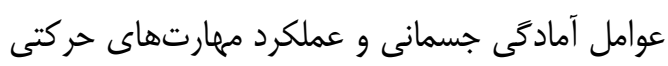

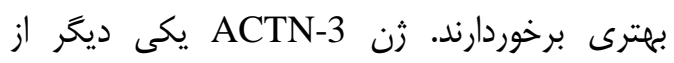
زنهاى مهم مرتبط با فنوتيبهاى زيربنايى عملكرد

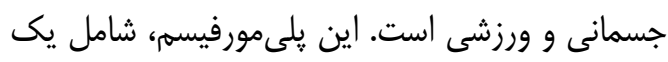

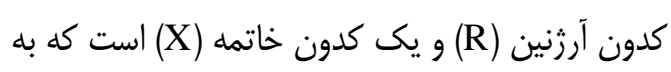

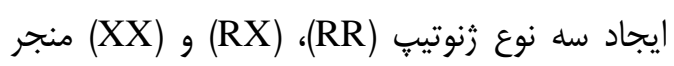

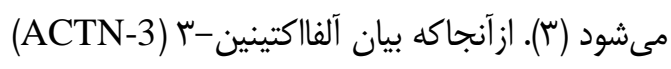
به تارهاى نوع II (فيبرهاى سريع كليكوليتيك) محدودشده است؛ بنابراين، كمبود اين يروتئين عملكرد

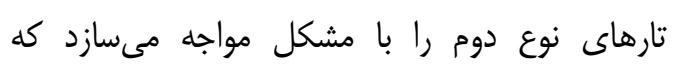
بزرگتر، داراى انقباض سريعتر و همجنين قدرت دمندتر از تارهاى نوع اول است (َٔ، ب). در اين ميان، عنوان

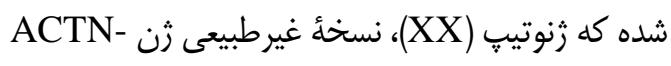

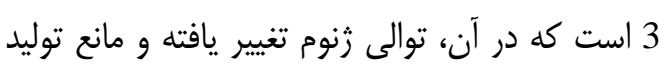

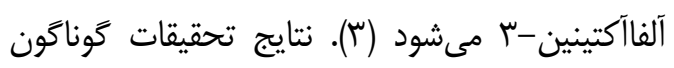

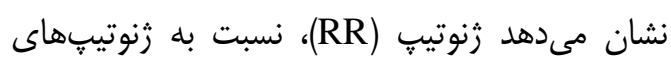

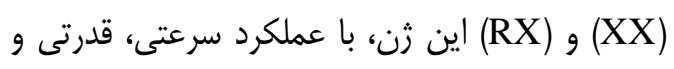

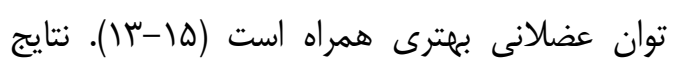
معدود تحقيقات انجامشده بر روى كودكان، اثر معنادار يلى مورفيسمهاى ثن ACTN-3 بر اضافهوزن و توان عملكردى يرش طول و ايستاده كودكان را نشان داده

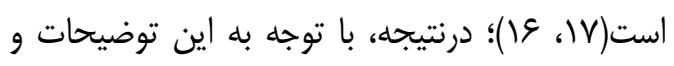

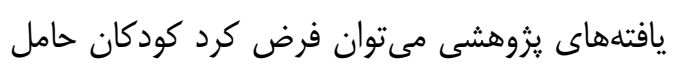

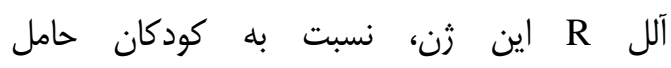
هموزيخوتهاى XX، بلدواسطة داشتن قدرت و توان عضلانى بيشتر، عملكرد حركتى و جسمانى بهترى بلى

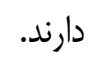

حال با توجه به ارتباط و تأثير گذارى زنوتيبهاى زن ACE و ACTN-3 بر عملكرد ورزشكاران نخبه،

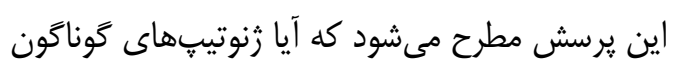

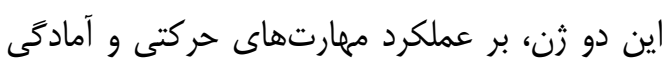
جسمانى كودكان نيز مؤثرند كه زيربناى مهارتهاى مهاى
مقدمه

كشف توانايىهاى بالقوه افر ادو و هدايت آنان به مسير درست، از مهمترين اهداف فعاليتهاى حوزه استعداديابى إنى

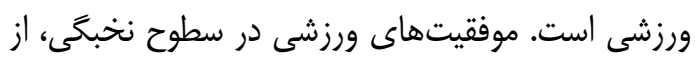

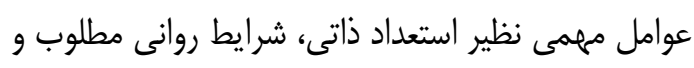

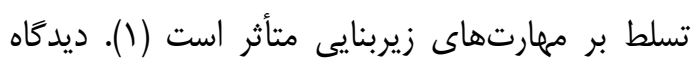

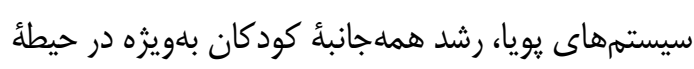

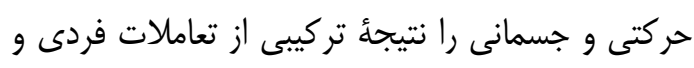

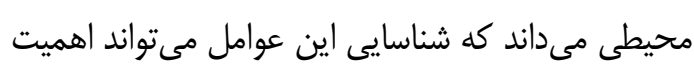
بسيارى در مشاركت در فعاليتهاى بدنى و هميَّنين شناسايى و هدايت استعدادهاى برتر ورزشى كودكان

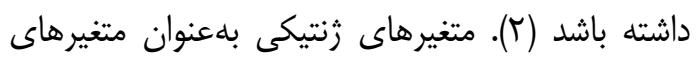

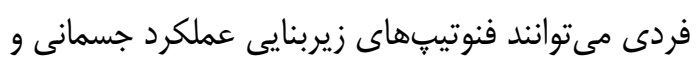

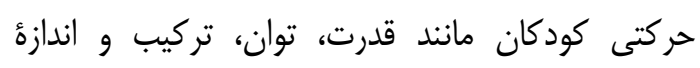

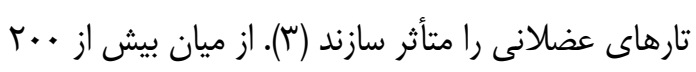

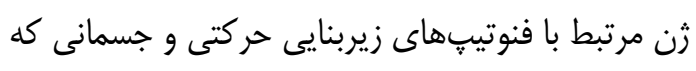
در سطوح نخبخى عملكرد مهارتى را متأثر مى كنند،

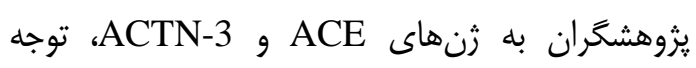
بيشترى نشان دادهاند (ه-"). زن ACE شامل حضور داشتن (I) يا حضور نداشتن

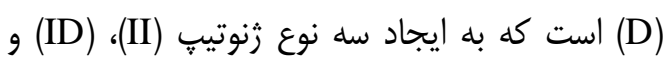
منجر مىشود (سا). افزايش بيشتر در قدرت رنوتئ (DD) عضلة جهارسر ران، افزايش سطح مقطع و حجم عضله

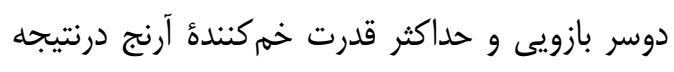

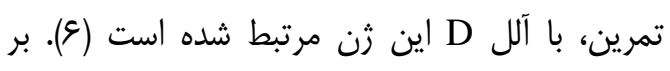

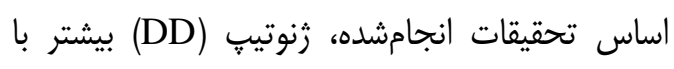

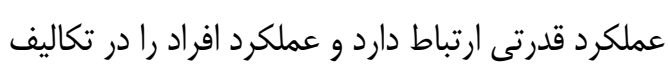

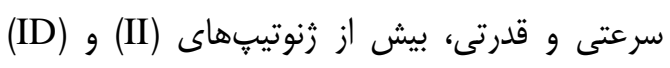

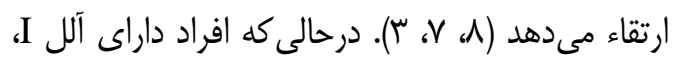
عملكرد استقامتى بهترى نسبت به افراد ديخر دارند (9).

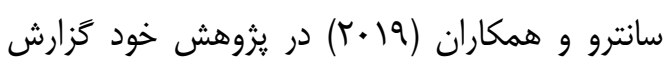

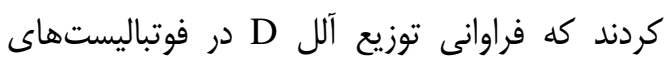
نخبه، نسبت به فوتباليستهاى آماتور بيشتر است ( • (1).

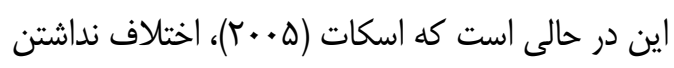

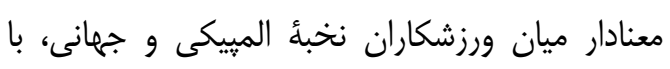

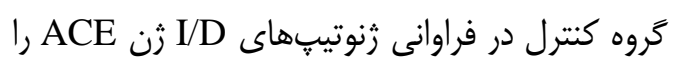

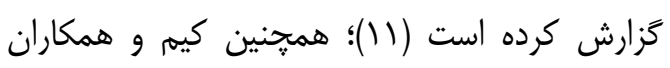

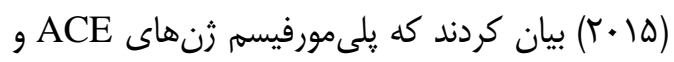


(از يلىمورفيسههاى I/D زن ACE و R577X ثن (ACTN-3

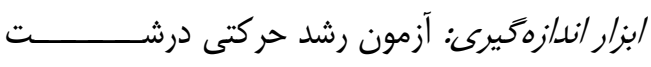

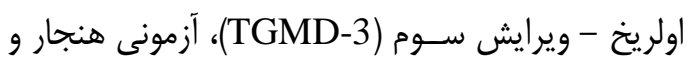

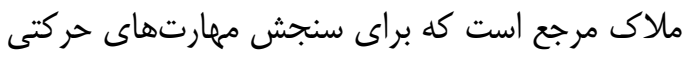

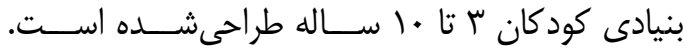

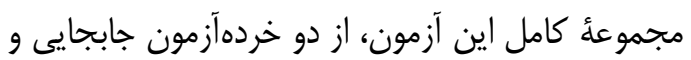

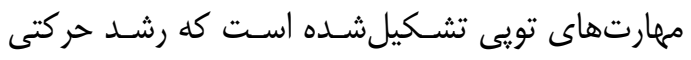

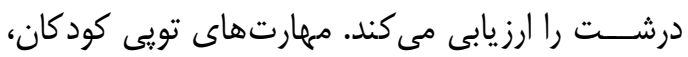
شامل هفت مهارت ضربه با باتوم به توب ثابت، ضربأَ

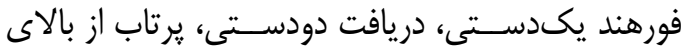

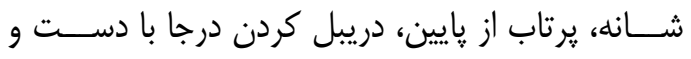

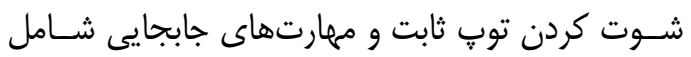
دويدن، يورتمه رفتن، لىلى رفتن، سكسكه دويدن، سر

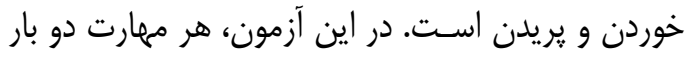

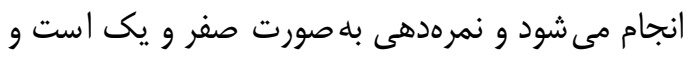
امتياز هاى بخش هاى هر م مهارت، جمع و درمجموع،

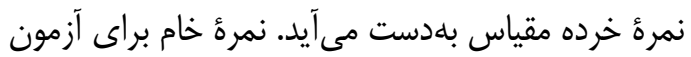
جابجايى بين · و ؤ اســت، درحالى كه نمره خام براى

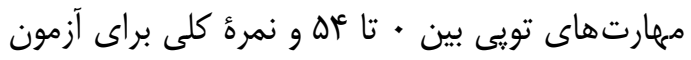

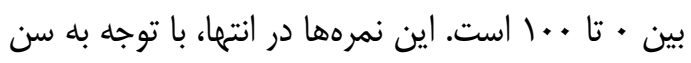
(به ماه)، در جدول نمرة ا ستاندارد محا سبه مى شود كه

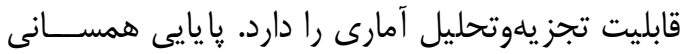

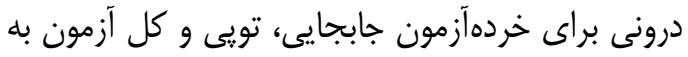

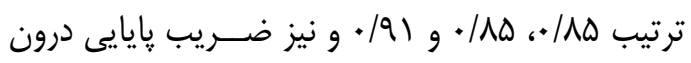

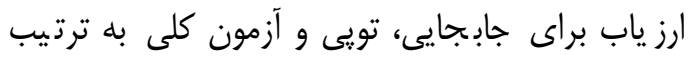

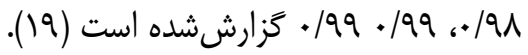

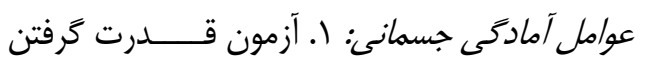

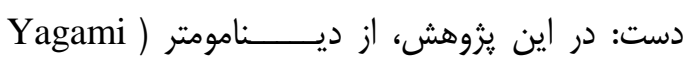
Dynamometer 100Kg, made in japan براى اندازهگيرى قدرت گرفتن دست استفاده شد. قدرت

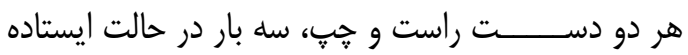

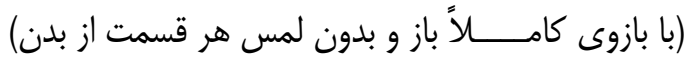

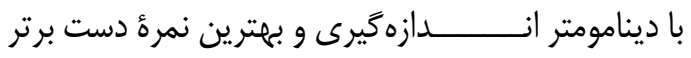

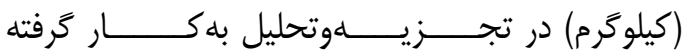

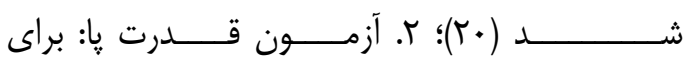

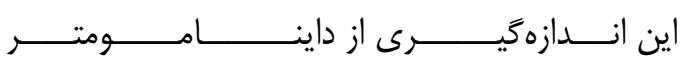

حركتى ورزشى در سط ـوح نخبكى هستند؟ در

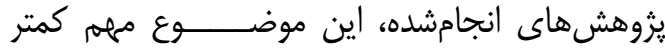

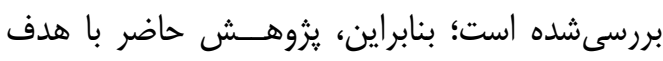

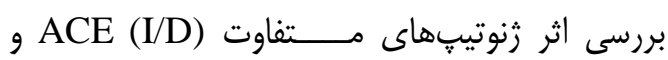
ACTN-3 (R/X) آمادگى جسمانى كودكان انجامشده است.

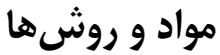

يزوهش حاضر، مطالعهاى توصيفى- مقطعى است.

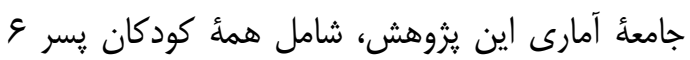

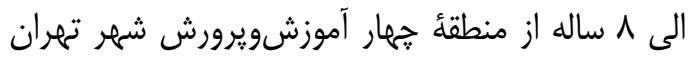
بود كه درنهايت، •ه نفر از ميان آنان، به شيوهُ آنهان

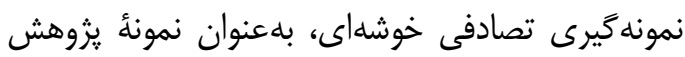

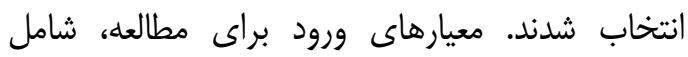
برخوردارى كودكان از سلامت جسمانى، ذهنى و حركتى و معيارهاى خروج، شامل وجود هركَونه اعتياد به مواد مخدر از سوى والدين و داشتن معلوليت و يا مشكلات

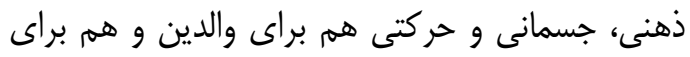

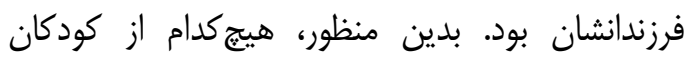
انتخابشده، در فعاليتهاى بدنى سازمانيافته مشاركت نداشتند. فرم رضايتنامة شخصى مشاركت در تحقيق،

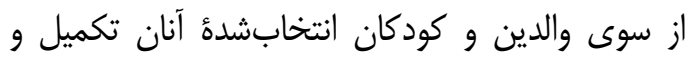

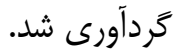
طرح آزمايشى: ييرو مكاتبات انجامشده ميان دانشگاه

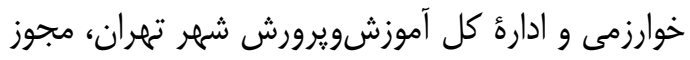

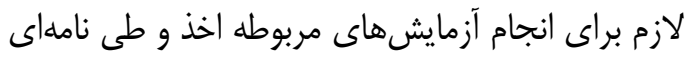

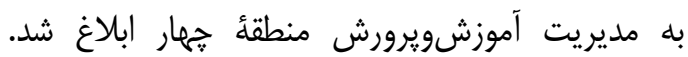

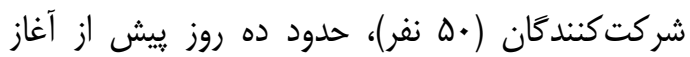

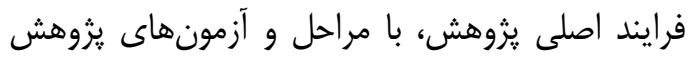
آشنا شدند. در ادامه، عملكرد آنان در اجراى مئل مهارتهات آنهاى حركتى بنيادى، شامل مهارتهاى حركتى جابجايى (دويدن، يرش افقى، لىلى كردن، تاختن، سر خوردن و سكسكه دويدن) و مهارتهاى تويى (يرتاب از بالاى لئى

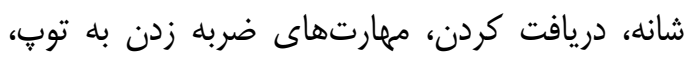

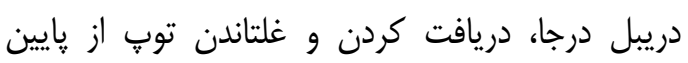

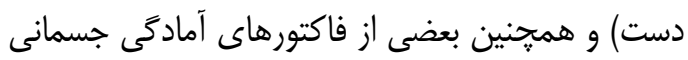

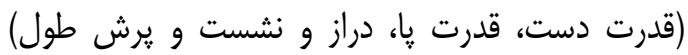

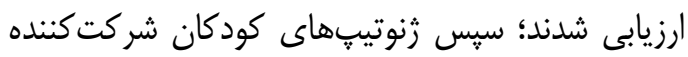


تجزيلوتحليل استفاده مىشود (•r).

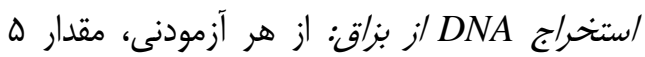

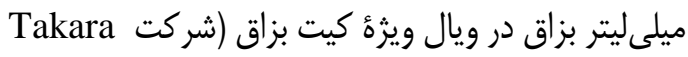
زاين) گرفته شد و با اجراى دستورالعمل آزمايشكاهى، DNA آزمودنىهاى يزوهش استخراج كرديد. در ادامه، غلظت و خلوص DNA بهدست آمده با استفاده از دستخاه

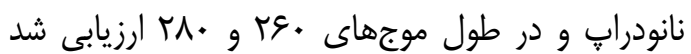
(ميانخين غلظت: 1OD260/280=1.2-7).

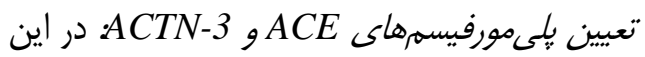

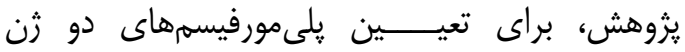

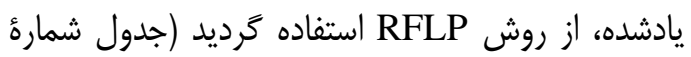
(). بر اساس اين، ابتدا نمونهاى از DNA استخر اجشده،

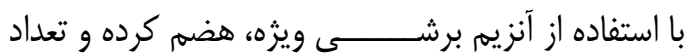

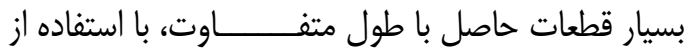

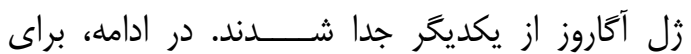

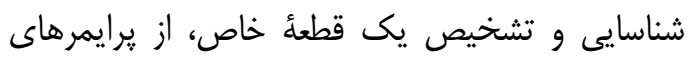

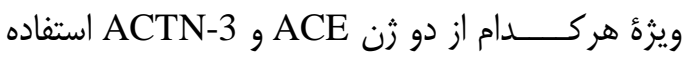

Yagami Dynamometer $300 \mathrm{Kg}$, made in ) استفاده گرديد؛ به اين ترتيب كه كودى روى (japan

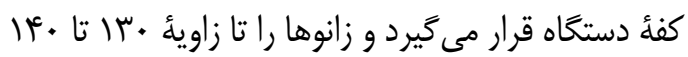

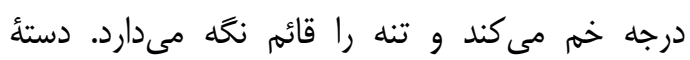

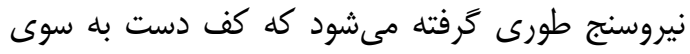
شخص باشد؛ سبس شخص به آهستخى اما با حداكثر نيرو بدون اينكه وضعيت قائم بدن تغيير نمايد، سعى به به به اله

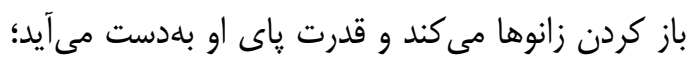

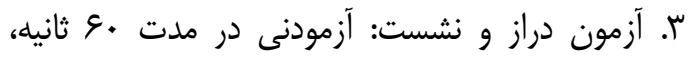

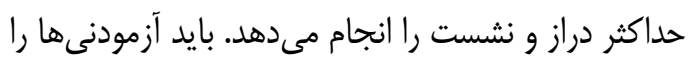

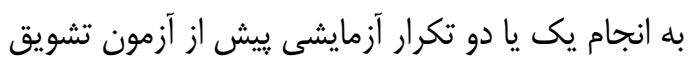

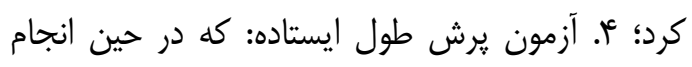

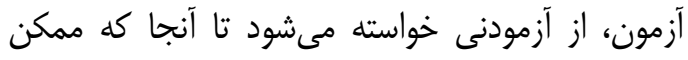

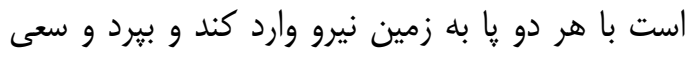

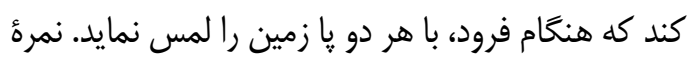

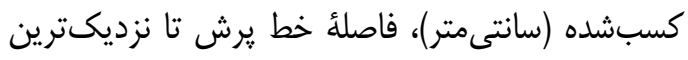
محل تماس ڤشت پاشنه با زمين است. آزمودنى اجازه

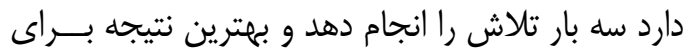

\begin{tabular}{|c|c|c|c|}
\hline آنزيم محدودكنندة برش & طول قطعه & رنوتيب & رن \\
\hline \multirow{3}{*}{ NcoI } & QQT & ID & ACE \\
\hline & rir & ID & \\
\hline & 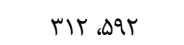 & II & \\
\hline \multirow[t]{3}{*}{ HpyF3I (DdeI) } & $\Lambda$ s.r. & $\mathrm{RR}$ & ACTN-3 \\
\hline & ג & $\mathrm{RX}$ & \\
\hline & 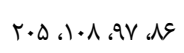 & $\mathrm{XX}$ & \\
\hline
\end{tabular}

\section{¿GATGTGGCCATCACATTCGTCAGAT} در طول قطعةٌ •r و مشــخصــات ACTN-3؛ رفت: CTGTTGCCTGTGGTAAGTGGG TGGTCACAGTATGCAGGAGGG

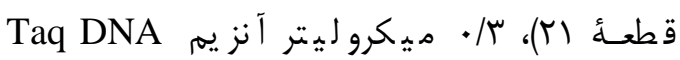
polymerase ادامه، واكنش PCR در دسـتخاه ترموسـايكلر (سـاخت كشور آمريكا، شركت TECHENE)

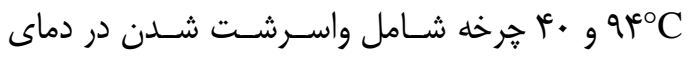
C $9{ }^{\circ} \mathrm{C}$ مدت ب دقيقه و درنهايت، طويل شـــن نهايى در دماى ماى

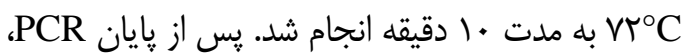

واكنش زنجيرهاى يليمراز (PCR): با بر نامهريزى

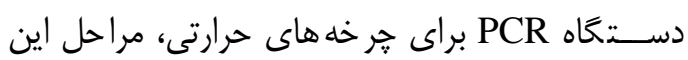

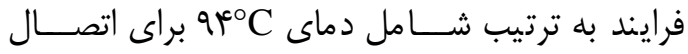

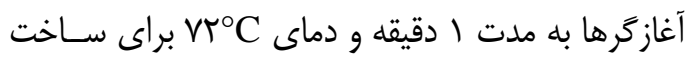

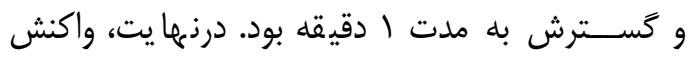

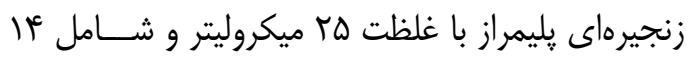

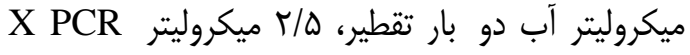

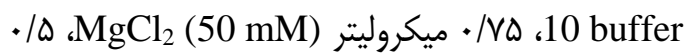
ميكروليتر dNTP، ا ميكروليتر از هر كدام از يرايمر ها

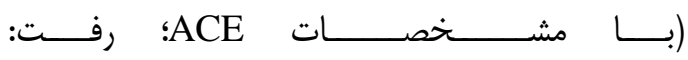
9 CTGGAGACCACTCCCATCCTTTCT : ش 
آكارز الكتروفورز ش-ــد و با اتيديوم رنغَآميزى كرديد تا

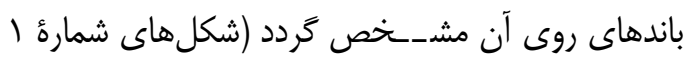

g
محصــول آن تحت تأثير آنزيم برشـى قرار كرفت تا در

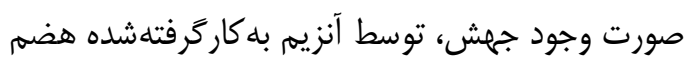

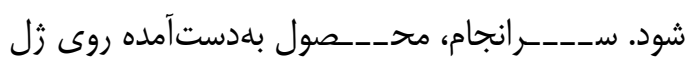

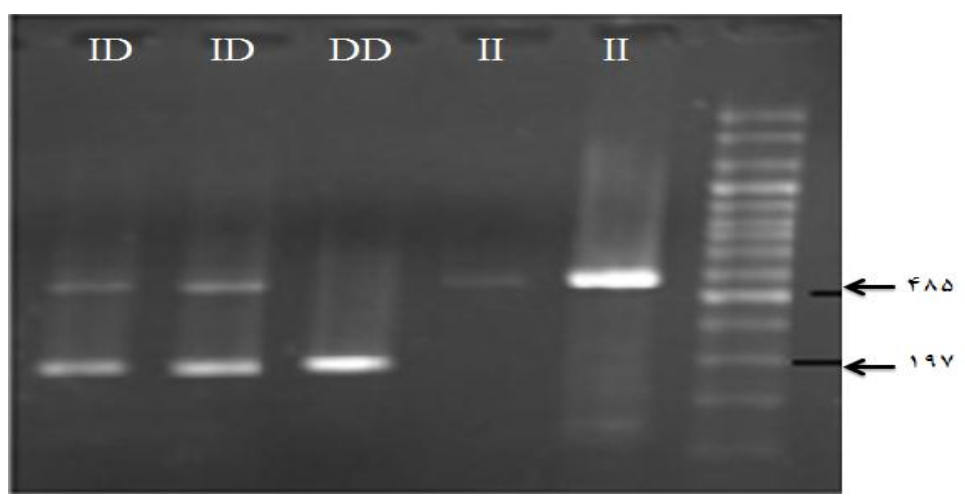

شكل شماره ا. زرنوتيب ACE

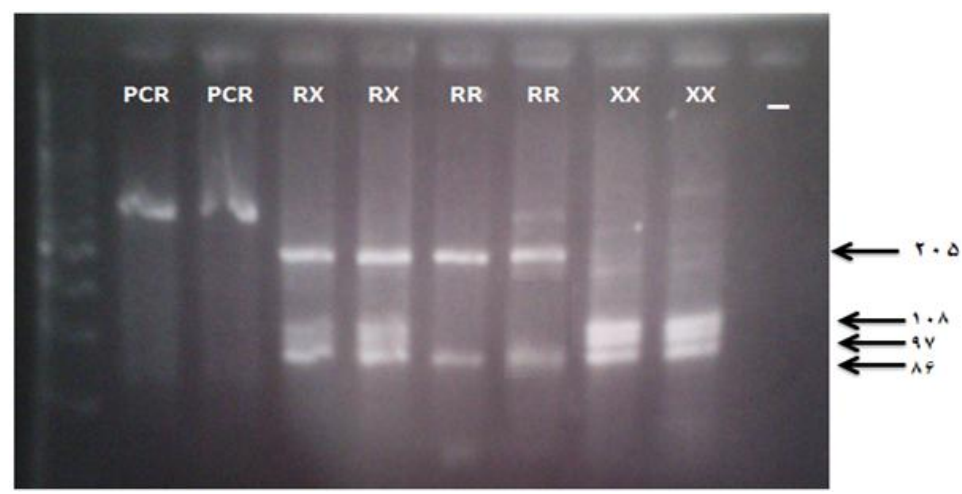

ACTN-3 شكل شمارؤ ب. زنوتيب

ويزخـــــهاى دموكرافيى آزمودنىها در جدول

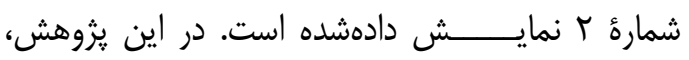

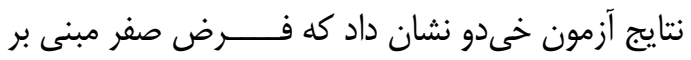

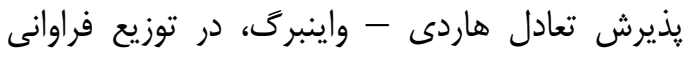

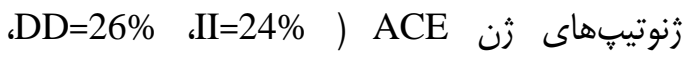
(ID=50\%

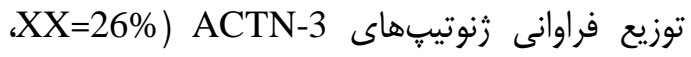
P=0.841) ، RR=40\%

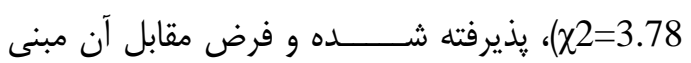

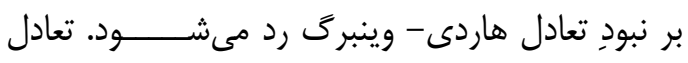

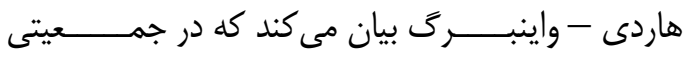

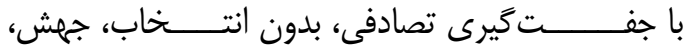

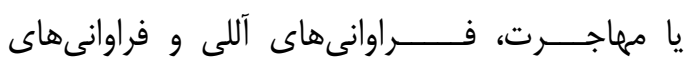

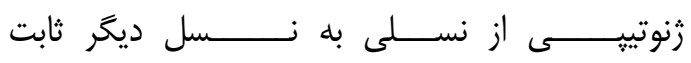

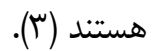

تجزيهوتحليل آمارى: در اين مطالعه، براى خلاصه

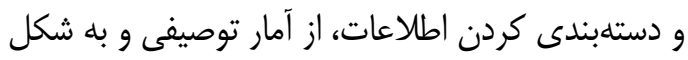

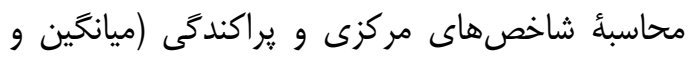

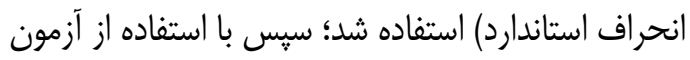

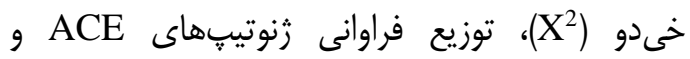
ACTN-3

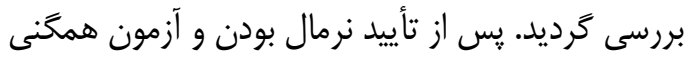
واريانس دادهها، از تحليل واريانس يكىطرفه (مقايسٔ سه

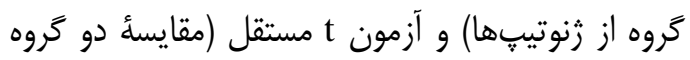

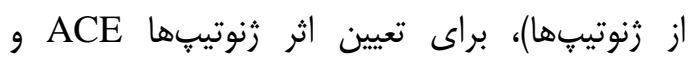
ACTN-3

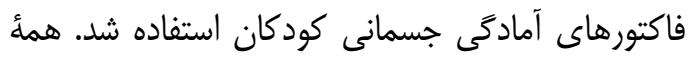

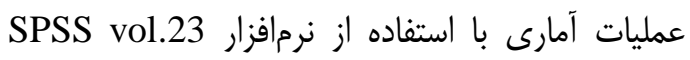

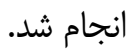
يافتههاى يزوهش تشل 
جدول شماره r. ويثَى هاى دموكَ افيك آزمودنى ها

\begin{tabular}{|c|c|}
\hline انحراف معيار 土 ميانكين & متغير \\
\hline$V / I \pm ז / \Gamma^{\circ} \Delta$ & سن (سال) \\
\hline $\mid r T / \Delta \pm \Delta N / T r$ & قد (cm) \\
\hline$r V / I \pm N / I T$ & وزن (kg) \\
\hline$r \pm 19 / 11$ & شاخص توده بدنى (kg/m2) \\
\hline
\end{tabular}

همجنين نتايج نشان داد كه ميان آزمودنىهاى

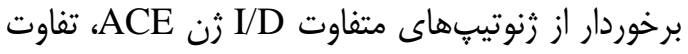
معنادارى در آزمون قدرت دست (P=0.036) F=2.85)

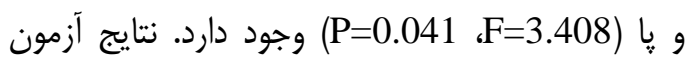
تعقيبى بونفرونى نشان داد كه قدرت دست (P=0.068)

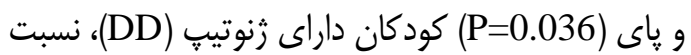
به كودكان داراى زنوتيّ (II)، بيشتر است.

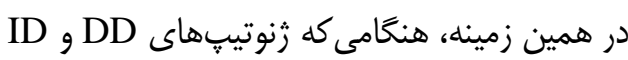
زن ACE، باهم تركيب شدند، نتايج آزمون t مستقل نشان داد كودكان داراى تركيب زنوتيبى (DD+ID)،

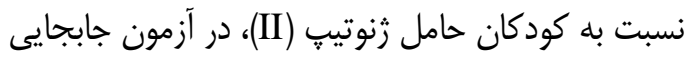

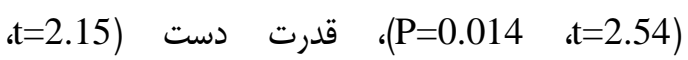
P=0.036) و قدرت پا (P=2.31)، Pa

$$
\text { بهترى دارند. }
$$

همانطور كه در جدول شمارة ب ملاحظه مىشود،

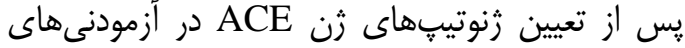

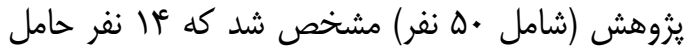

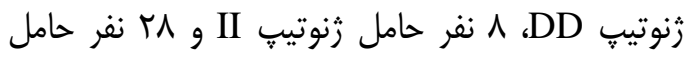
زنوتيّ ID بودند؛ همجنين نتايج آزمون تحليل واريانس يكىطرفه نشان داد كه برخلاف مهارتهاى توبى ميان

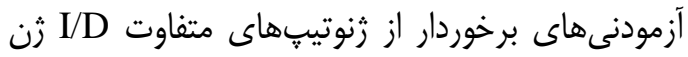

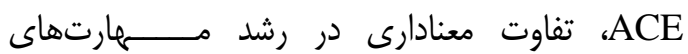

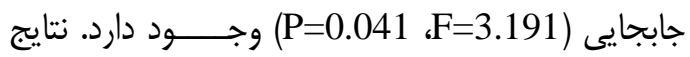

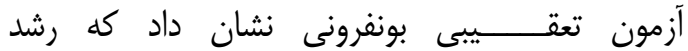

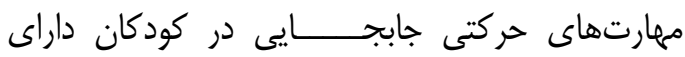

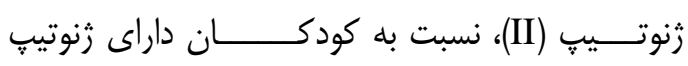

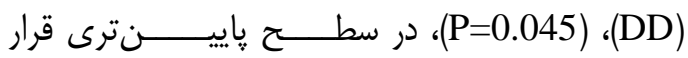
دارد. - ( - n

\begin{tabular}{|c|c|c|c|c|}
\hline \multicolumn{5}{|l|}{ رن ACE } \\
\hline \multirow{2}{*}{$\begin{array}{c}\mathrm{DD}+\mathrm{ID} \\
(\mathrm{n}=42)\end{array}$} & \multicolumn{3}{|c|}{ رنوتيبهاى ACE } & \multirow[t]{2}{*}{ متغيرها } \\
\hline & $\mathrm{II}(\mathrm{n}=8)$ & $\mathrm{DD}(\mathrm{n}=14)$ & ID $(n=28)$ & \\
\hline 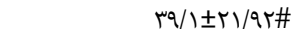 & $r g / / \pm V V / \Lambda F$ & $r q / r \pm r \mid / r r \#$ & $r q / r \pm \cdot v / r)$ & مهارتهاى جابجايى \\
\hline$F \Delta / \mathcal{F} \pm F V / r \varepsilon$ & $\Gamma \varphi / F \pm T \Delta / \wedge q$ & $|\varphi / \Delta \pm| f / \Delta \mid$ & $F \Delta / r \pm I F / \Delta F$ & مهارتهاى تويى \\
\hline $\mid r / r \pm r r / q 9$ & $1 . / r \pm \cdot 1 / \Delta+q$ & $\mid r / r \pm \lambda r / \Delta Q \#$ & $11 / r \pm q r / I r$ & قدرت دست \\
\hline $1.9 / \% \pm r \cdot / 99 \#$ & $q V / / r \pm \Delta \cdot / r q$ & $\| r / N I \pm r N / Q T \#$ & $1 \cdot V / I T \pm r r / \Delta F$ & قدرت پا \\
\hline $1 \cdot r / \mid r \pm r \Delta / r 1$ & $9 \Delta / \backslash \Delta \pm 9 Y / 9 \Lambda$ & $1.9 / 1 F \pm 1 \% / r r$ & $1.1 / 11 \pm q \varepsilon / \wedge \Lambda$ & مِرش طول \\
\hline$r V / F \pm I r / I V$ & $r V / F \pm \cdot 1 / \cdot r$ & $r q / \wedge \pm \cdot \cdot / \Delta \Delta$ & $r g / Q \pm s V / \Delta r$ & دراز و نشست \\
\hline
\end{tabular}

تعقيبى بونفرونى نشان داد كودكان داراى زنوتيڤ (RR)، نسبت به كودكان داراى زنوتيب (XX)، در مهارتهاى نعاي

جابجايى (P=0.009)، در سطح بالاترى قرار دارند.

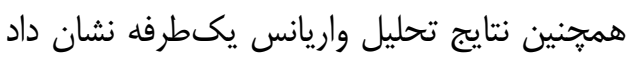

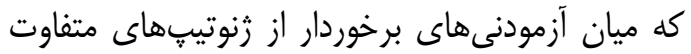
R/X ثن RCTN-3

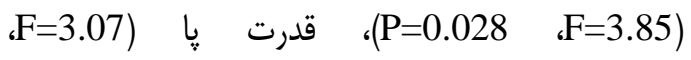

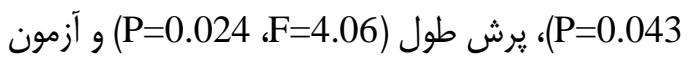
دراز و نشست (P=10.04، F=0.000) وجود دارد. نتايج آزمون تعقيبى بونفرونى نشان داد كودكان داراى زنوتيب
همانطور كه در جدول شمارة ب ملاحظه مىشود،

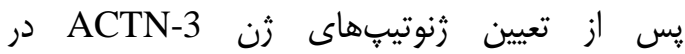

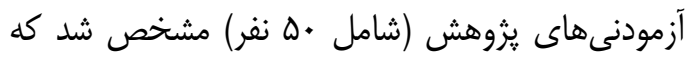

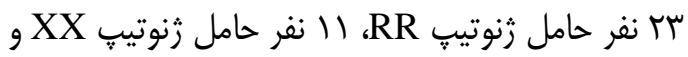
عا نفر حامل زنوتيب RX بودند. بدين منظور، نتايج تحليل واريانس يكسرفه نشان داد كه برخلاف رشد

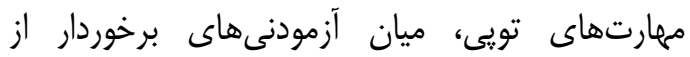

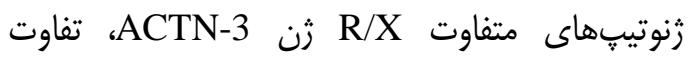

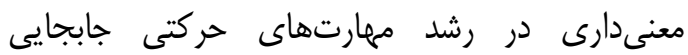
وجود دارد. نتايج آزمون 


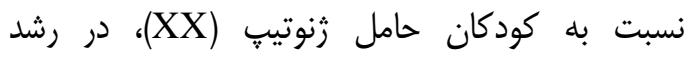

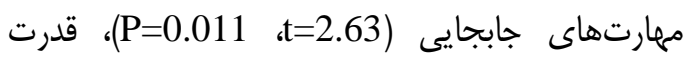
دست (P=2.18)،

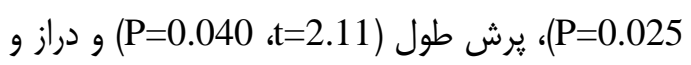

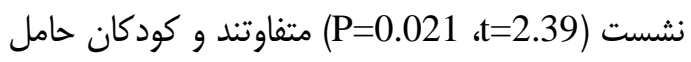
آلل R، از سطح رشد بالاترى در اين مؤلفهها برخوردار هستند.
(RR) دست (P=0.031)، (P=0.042)، قدرش طول (P=0.029) بالاترى قرار دارند. از سويى، هنخامى كه زنوتيبهاى RR و RX ACTN-3 نشان داد كودكان داراى تركيب زنوتييى (RR+RX)،

\begin{tabular}{|c|c|c|c|c|}
\hline & \multirow{3}{*}{ متغيرها } \\
\hline \multirow{2}{*}{$\begin{array}{c}\mathrm{RR}+\mathrm{RX} \\
(\mathrm{n}=39)\end{array}$} & \multicolumn{3}{|c|}{ رنوتيبهاى ACTN-3 } & \\
\hline & $\mathrm{RR}(\mathrm{n}=23)$ & $\mathrm{XX}(\mathrm{n}=11)$ & $\mathrm{RX}(\mathrm{n}=16)$ & \\
\hline$r q / r \pm r r / \Lambda 1 \#$ & 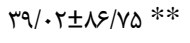 & 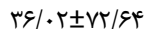 & $r N \cdot r \pm r \mid V T$ & مهارتهاى جابجايى \\
\hline$F \Delta / r \pm 9 q / ৭ q$ & $r Q / \cdot r \pm V T / E T$ & $|\kappa \Psi / \cdot \Delta \pm \lambda| / F \mid$ & $r \Delta / \cdot r \pm g r / V \Delta$ & مهارتهاى تويى \\
\hline$|r / r \pm r \cdot / V| \#$ & $\mid r / \cdot r \pm \wedge 9 / V \Delta \#$ & $1 . / . r \pm r M / / 4 \Lambda$ & $11 / T \pm r \varepsilon / D 1$ & قدرت دست \\
\hline $1 . q / 1 f \pm v q / \cdot \wedge \#$ & $111 / 1 r \pm r v / q . \#$ & $99 / 1 r \pm 11 / 1 V$ & $1 \cdot V / \triangle \Delta \pm r V / V^{c}$ & قدرت يا \\
\hline $1 . F / 1 r \pm 11 / 99 \#$ & $1 \cdot V / / V \pm 11 / 9 Y^{\prime} \#$ & $q_{D} / \cdot r \pm / F / \wedge r$ & 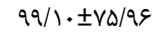 & ميرش طول \\
\hline$r N / \Lambda \pm \Lambda F / \Delta r \#$ & $r r / \cdot \Lambda \pm M r / I V * *$ & $r r / .9 \pm 1 N / F V$ & $r r / \& \pm \Lambda 1 / r V$ & دراز و نشست \\
\hline
\end{tabular}

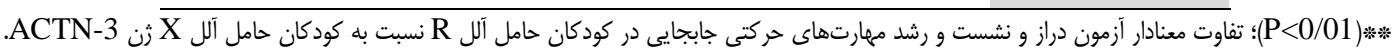

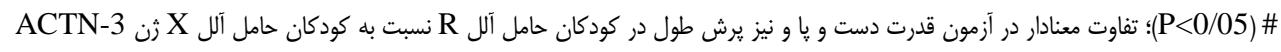

قدرت يا، يرش طول و دراز و نشست) در كودكان انجام كرفت. بخشى از نتايج اين يزوهش نشان داد كه كودكان

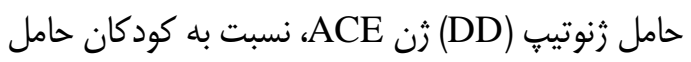

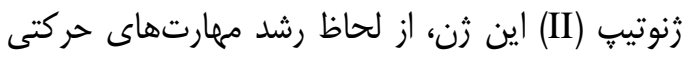

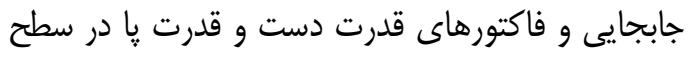

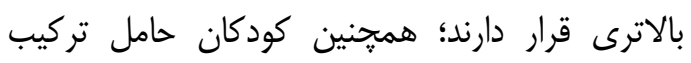

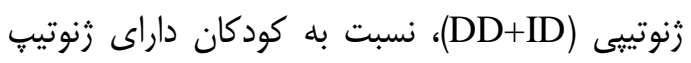

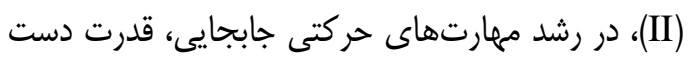

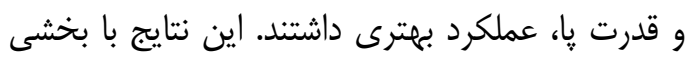

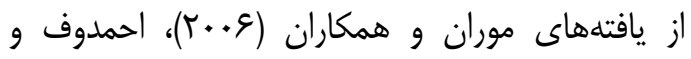

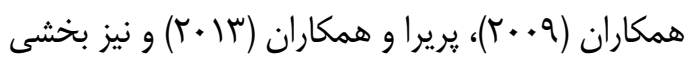

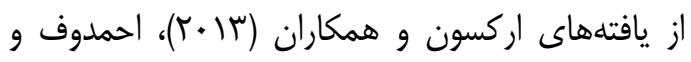

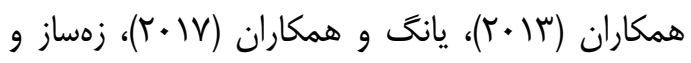

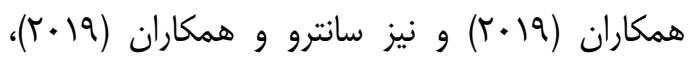

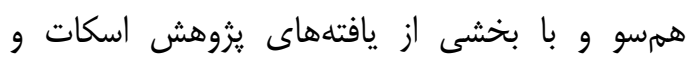

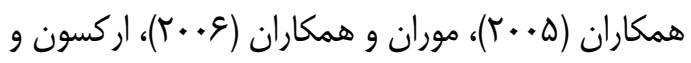

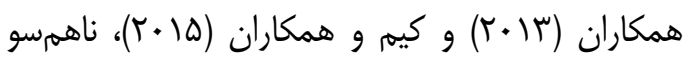

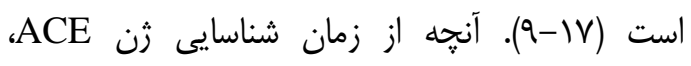

\section{بحث و نتيجه}

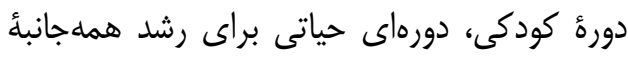

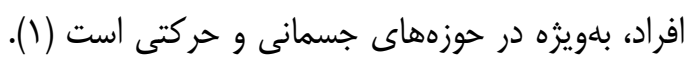

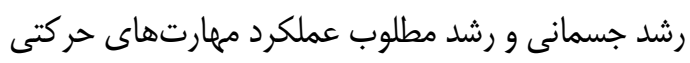
(شامل مهارتهاى جابجايى و تويى)، زمينٔ مشاركت

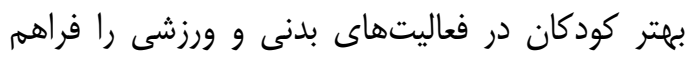

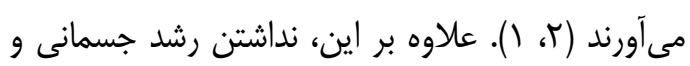

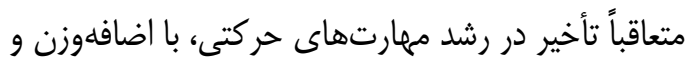

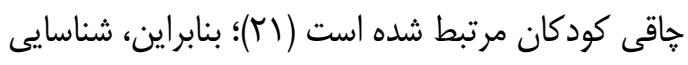

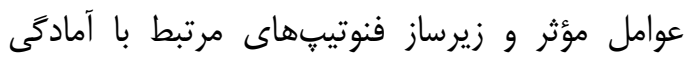
جسمانى و عملكرد مهارتهاى حركتى، علاوه بر داشتن

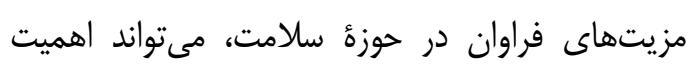
بسيارى در شناسايى و هدايت استعدادهاى برتر ورزشى درى دوان

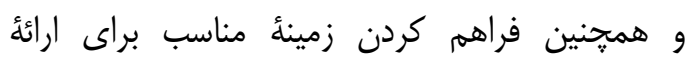

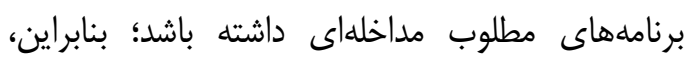
يزوهش حاضر با هدف بررسى اثر يلىمورفيسمهاى مداى

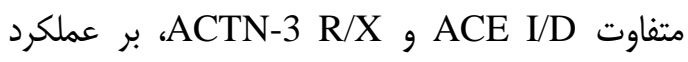
مهارتهاى حركتى (مهارتهاى حركتى جابجايى و تويى) و بعضى از عوامل آمادَى جسمانى (قدرت دست، حهاب، 
يُوهش حاضر نيز مؤيد آن است، كودكان برخوردار از

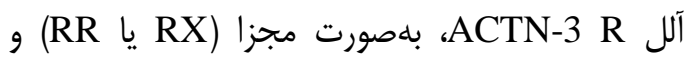

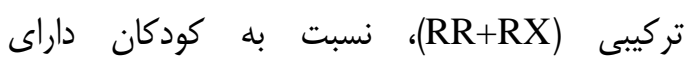

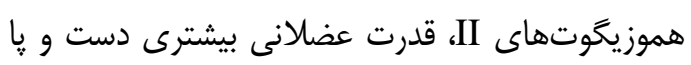

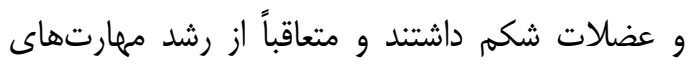

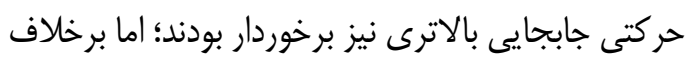

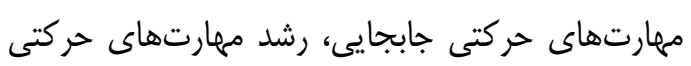

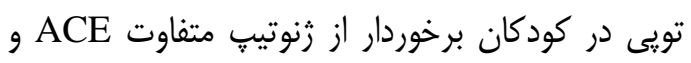
ACTN-3

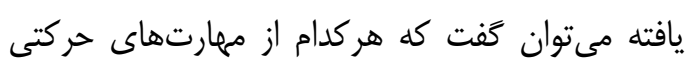

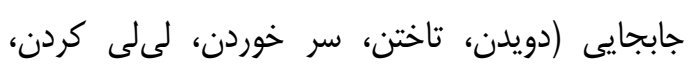

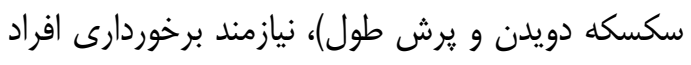

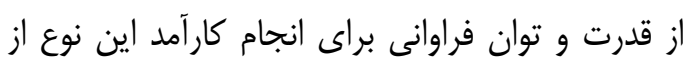

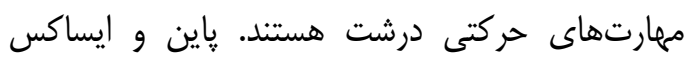
محلا.IV)

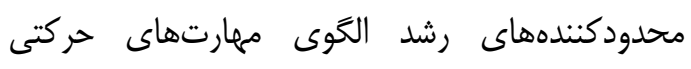

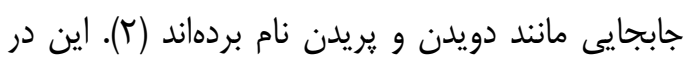

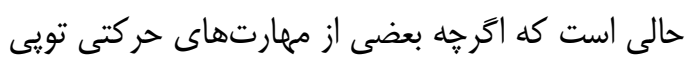

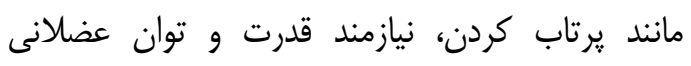

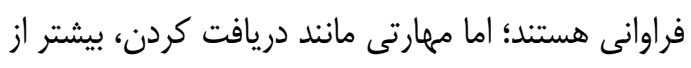

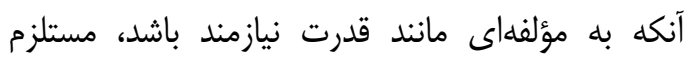

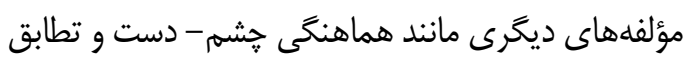

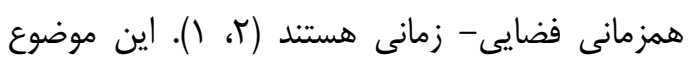

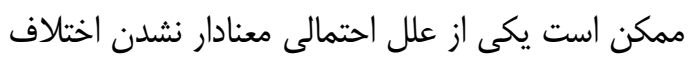

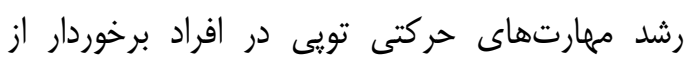

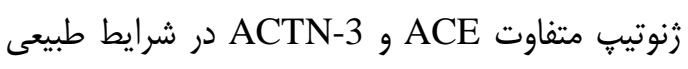

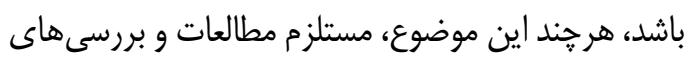
بيشترى است.

بر اساس نتايج اين بزوهش، كودكان برخوردار از

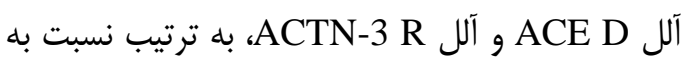

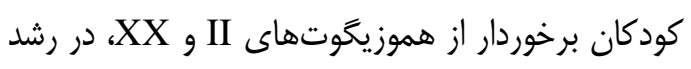

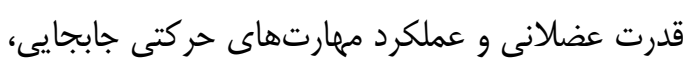

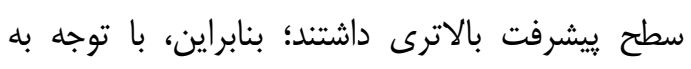

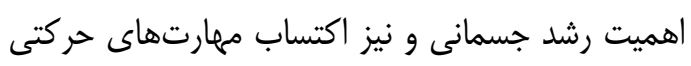

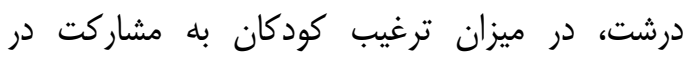

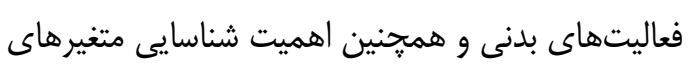

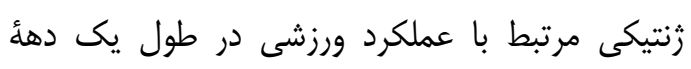
كذشته، مىتوان يل ارتباطى دوطرفهاى را ميان رشد
بهعنوان يك ثن مؤثر در عملكرد جسمانى و ورزشى ائى

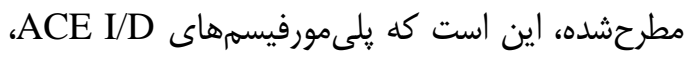

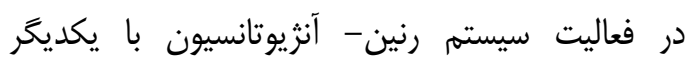

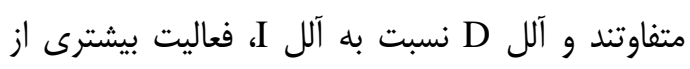

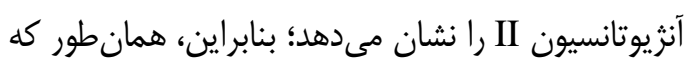
نتايج يُروهش حاضر نيز نشان مى آندند، كودكان حامل

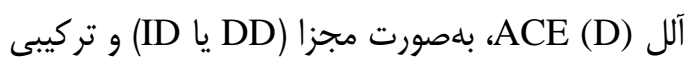
(DD+DI)

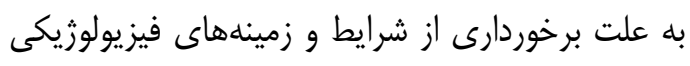

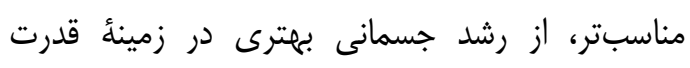

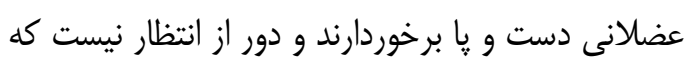

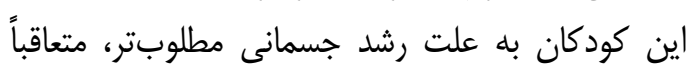
رشد مهارتهاى حركتى جابجايى سطح بالاترى نيز

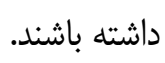
بخش ديكرى از نتايج يزووهش حاضر نشان داد

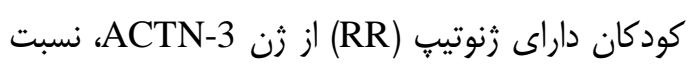

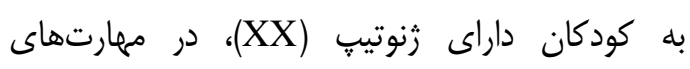

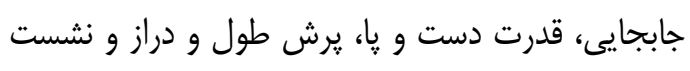

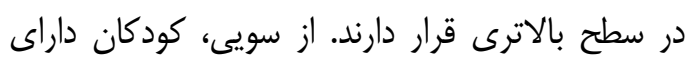

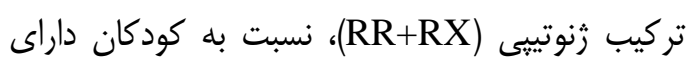

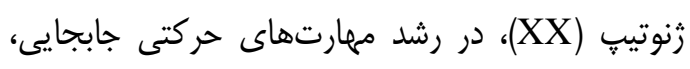

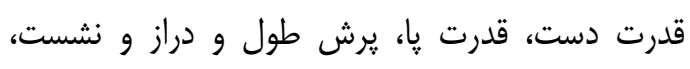

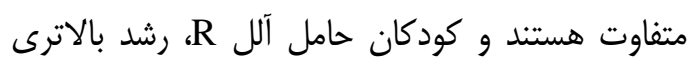

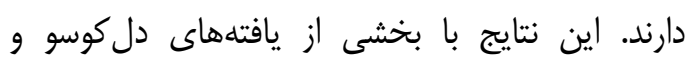

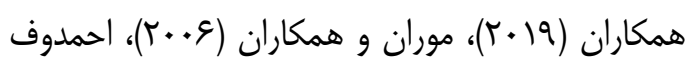

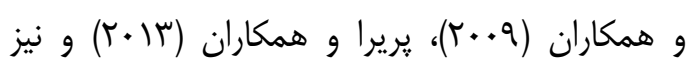

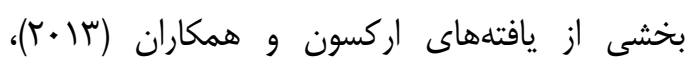

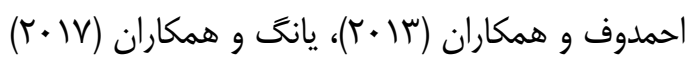

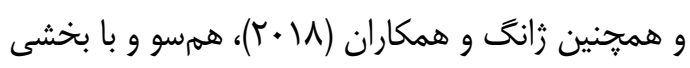

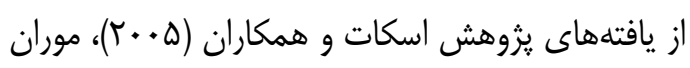

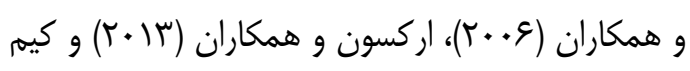

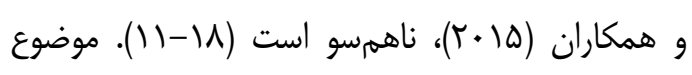

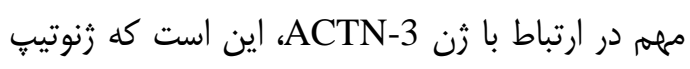
(XX)

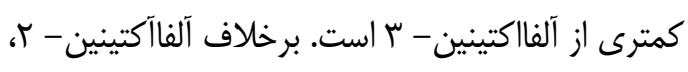

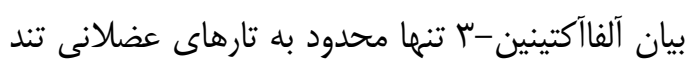

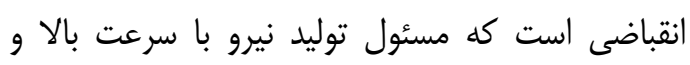
قدرت زياد هستند (9-ب)؛ ازاينرو، همانطور كه نتايج باني 


$$
\begin{aligned}
& 3 \text { R/X } \\
& \text { مهارتهاى ورزشى سطح بالا متصور شد. } \\
& \text { كد /خلاق: }
\end{aligned}
$$

\section{References}

1. Gallahue DL, Ozmun JC, Goodway J. Understanding motor development infants children adolescents and adults. $1^{\text {th }}$ ed. Mcgraw hill Boston Publication. 2006;P.7399.

2. Payne VG, Isaacs LD. Human motor development a lifespan approach. $3^{\text {th }}$ ed. Routledge Publication. 2017;P.231-46.

3. Collins M. Genetics and sports. $2^{\text {th }}$ ed. Karger Med Sci Publication.2009;P.101-9. 4. Ahmetov II, Gavrilov DN, Astratenkova IV, Druzhevskaya AM, Malinin AV, Romanova EE, et al. The association of ACE andACTN3 and PPARA gene variants with strength phenotypes in middle school age children. J Physiol Sci 2013;63:79-85. doi. 10.1007/s12576-012-0233-8.

5. Bray MS, Hagberg JM, Perusse L, Rankinen T, Roth SM, Wolfarth B, et al. The human gene map for performance and health related fitness phenotypes the 2006-7. Med Sci Sport Exe2009;41:34-72. doi.10.1249/MSS.0b013e3181844179.

6. Williams AG, Day SH, Folland JP, Gohlke P, Dhamrait S, Montgomery HE. Circulating angiotensin converting enzyme activity is correlated with muscle strength. Med Sci Sport Exe 2005;37:944.

7. Ahmetov II, Williams AG, Popov DV, Lyubaeva EV, Hakimullina AM, Fedotovskaya ON, et al. The combined impact of metabolic gene polymorphisms on elite endurance athlete status and related phenotypes. Hum Gene 2009;126:751. doi.10.1007/s00439-009-0728-4.

8. Pereira A, Costa AM, Leitao JC, Monteiro $\mathrm{AM}$, Izquierdo M, Silva AJ, et al. The influence of ACE ID and ACTN3 R577X polymorphisms on lower-extremity function in older women in response to high speed power training. BMC Geriatr2013;13:131. doi.10.1186/1471-2318-13-131.

9. Zehsaz F, Safabakhsh AH, Farhangi N, Keynezhad N, Monfaredan A, Ghahramani M. Do ACE and CKMM gene variations have potent effects on physical performance in inactive male adolescents? Mole Biol Rep2019;46:1835-43.

$$
\begin{aligned}
& \text { عوامل جسمانى (مانند قدرت) و كسب شايستخى و تبحر } \\
& \text { در اجراى مهارتهاى حركتى جابجايى، دارا بودن نيمرخ }
\end{aligned}
$$

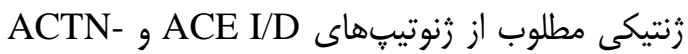

10. Santoro GF, Mello KD, Oliveira Netto ZC, Pfutzenreuter G, Bassan JC, Salgueirosa FDM. The influence of ace i/d gene polymorphism in amateur american football athletes in brazil. Rev Brasileira Med Esporte2019;25:460-3. doi.10.1590/1517869220192506198909.

11. Scott RA, Moran C, Wilson RH, Onywera V, Boit MK, Goodwin WH, et al. No association between angiotensin converting enzyme gene variation and endurance athlete status in Kenyans. Comp Biochem Physiol Mole Int Physiol 2005;141:169-75.

doi.10.1016/j.cbpb.2005.05.001.

12. Kim K, Ahn N, Cheun W, Byun J, Joo Y. Association of angiotensin converting enzyme $\quad I / D$ and $\alpha$-actinin-3 R577X genotypes with growth factors and physical fitness in Korean children. Korean J Physiol Pharmacol 2015;19:131-9. doi.10.4196/kjpp.2015.19.2.131.

13. Coso J, Hiam D, Houweling P, Perez LM, Eynon N, Lucia A. More than a speed gene ACTN3 R577X genotype trainability muscle damage and the risk for injuries. European J Appl Physiol 2019;119:49-60. doi.10.1007/s00421-018-4010-0.

14. Erskine RM, Williams AG, Jones DA, Stewart CE, Degens H. The individual and combined influence of ACE and ACTN3 genotypes on muscle phenotypes before and after strength training. Scandinavian J Med Sci Sport 2014;24:642-8. doi.10.1111/sms. 12055

15. Yang R, Shen X, Wang Y, Voisin S, Cai $\mathrm{G}, \mathrm{Fu} \mathrm{Y}$, et al. ACTN3 R577X gene variant is associated with muscle related phenotypes in elite Chinese sprint/power athletes. J Str Cond Res 2017;31:1107-15. doi.10.1519/JSC.0000000000001558.

16. Moran CN, Vassilopoulos C, Tsiokanos A, Jamurtas AZ, Bailey ME, Montgomery $\mathrm{HE}$, et al. The associations of ACE polymorphisms with physical, physiological and skill parameters in adolescents. European J Hum Gene 2006;14:332-9. doi.10.1038/sj.ejhg. 5201550 


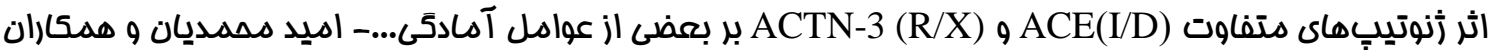

17. Zhang Q, Cao Y, Chen J, Shen J, Ke D, Wang $\mathrm{X}$, et al. ACTN3 is associated with children's physical fitness in Han Chinese.
Mole Gene Genom2019;294:47-56. doi.10.1007/s00438-018-1485-7 


\title{
Effect of ACE (I/D) and ACTN-3 (R/X) Genotypes on some Factors of Physical Fitness and Performance of Motor Skills in 6-8-Year-Old Children
}

\author{
Mohammadian $O^{1,2^{*}}$, Bahram $A^{1}$, Ghadiri $F^{1}$, Yaali $R^{l}$, Mazaheritayarani $Z^{3}$
}

(Received: August, 42020

\begin{abstract}
Introduction: The identification of the factors affecting the physical performance and development of children's motor skills can be of great importance in participating in physical activities, preventing overweight and obesity, as well as identifying and guiding the top talented children in sport. Therefore, this study aimed to investigate the effect of different ACE (I/D) and ACTN-3 $(\mathrm{R} / \mathrm{X})$ genotypes on some factors of physical fitness and motor skill performance in children.
\end{abstract}

Materials \& Methods: The statistical population of this study included 6-8-yearold school children in Tehran, Iran. In total, 50 cases were selected randomly using the cluster-sampling method. The data were collected using the Physical Fitness Test, Test of Gross Motor Development-Third Edition (TGMD-3), and PCR for the determination of ACE and ACTN-3 polymorphism. Furthermore, a one-way analysis of variance and independent t-test were used to analyze the study data. A pvalue less than 0.05 was considered statistically significant .

Ethics code: IR.KHU.REC.1399.010
Accepted: December, 5 2020)

Findings: The results showed that children carrying allele D of ACE gene, (DD or ID genotype), compared to those with II genotype $(\mathrm{P}<0.05)$, and the cases carrying the allele R of ACTN-3 gene (RR or RX genotype), compared to those with $\mathrm{XX}$ genotype $(\mathrm{P}<0.05)$ had more muscular strength in hand and foot, as well as higher levels of locomotor skills. However, no significant difference was observed regarding the performance of ball motor skills $(\mathrm{P}>0.05)$.

Discussions \& Conclusions: According to the results of the study, it can be said that the children carrying DD or ID genotype of ACE and RR or RX genotype of ACTN-3 had a higher level of physical development and consequently higher levels of locomotor skill performance. Therefore, if they are provided with desirable environmental conditions, they will be able to do sport skills accompanied by higher levels of performance.

Keywords: Children, Genotype, Motor development, Phenotype, Physical fitness, Sport gene

1. Dept of Motor Behavior, Faculty of Physical Education and Sport Sciences, Kharazmi University, Tehran, Iran

2. Dept of Physical Education and Sport Sciences, Iran University of Science and Technology, Tehran, Iran

3. Basic Medical Science Research Center, Histogenotech Co., Tehran, Iran

*Corresponding author Email: omohammadian10@gmail.com

Scientific Journal of Ilam University of Medical Sciences 